\title{
Løjtnant Voldbyes breve fra 1864
}

\author{
Ved J. W. G. Norrie.
}

II.

13.

Sebbelev, d. 18 de fbr. 1864 .

Kjære broder!

Dit brev med indlæg modtog jeg igaar. Du taler om, at der maaske ligger breve undervejs, som jeg ikke har faaet og tvivler ogsaa om, hvorvidt jeg faaer det. Jeg har modtaget breve, daterede som f $\phi$ lger: fra fader d. $1.0 \mathrm{~g} 9$. ds., fra Ida ogsaa d. 1ste, fra dig d. 3. og 11., men jeg antager ikke, der er flere af sendte og trøster mig med det.

Vi ligger endnu i ro og mag her paa Als og have nu været her i 8 dage. Efter sigende skulde vi blive her endnu indtil paa mandag d. 22de, hvis vi ikke rykke ud idag; der gaaer nemlig det rygte, at tydskerne idag agte at angribe Dybbølstillingen. Ja, lad dem bare komme, de skulle sandelig faae en modtagelse her, som bestemt vil kildre dem svært $i$ næsen. Det er vistnok en af de stærkeste stillinger, man kan tænke sig. Grunden, hvorfor vi have ligget saa længe her, er, at 18de rgmts tour er gaaet over, fordi vi have haft det saa strengt. Saadan en lille ferie er for $\phi v-$ rigt gandske behagelig, naar man blot ikke, som tilfældet er med mig, er ford $\emptyset \mathrm{mt}$ til at sidde og gnide paa en stol hele dagen igiennem, min fod har nemlig hidindtil ikke tilladt mig at gaae udenfor en $d \phi r$ f $\phi r e n d$ idag og vil endnu ikke rigtig gjфre gavn, men bedre er den dog, og jeg haaber, den kommer sig, inden vi atter skulle til at kløe tydskerne; det vilde være en forbandet ærgerlig historie, om man for saadan en pjalt fods skyld skulde gaae glip af en festdag. Kan du tænke dig, at tydskernes frækhed 
gaaer saa vidt, at de igaar ved en parlamentair lod spфrge, om vi inte vilde være saa artige at rømme Als; jo nu komme vi strax. De ere jo gale. Idag er der kommen nogle overløbere til os, der have erklæret, at de kjendte Dybbøl og havde rigtignok ikke lyst til at lade sig slagte der. -

Du kan troe, feltlivets anstrengelser ere uhyre, det vil sige, de vi nu for tiden døie. Vi boe 4 mand, lt. Bruun, Helms, doktor Videbech og jeg, sammen hos Hans Smidt, Kroget Hjørne, i Sebbelev; der have vi 3 smaastuer (ja, i den ene kan der kun være 1 menneske), og denne lille lejlighed er efterhaanden blevet samlingsstedet for al gemytlighed i hele egnen. Alle andre steder h $\phi$ rer man, de kjede sig, men her — ja du skulde bare være her en dag, du vilde undre dig over, hvad man med en god villie kan præstere i retning af at leve godt - rigtigt godt. Vi leve af naturalforplejning og lidt til. Hver morgen faaer vi leveret, ligesom mandskabet, kjød, flæsk, br $\phi \mathrm{d}$ og brændevin, men seer du, naar vi faaer kjød er det jo til 4 mand $i$ et stykke, og det stykke antager da som oftest skikkelse af den delikateste oxemørbrad, man kan tænke sig, og nydes afvexlende som steg eller beuf. Vores madamme er en fortrinlig kokkepige. Vi have altid en god viinbeholdning, og naar man saa dertil f $ø$ ier de leveringer, lt. Helms og doctoren faaer hjemme fra (fra herregaarde) saasom: stegte ænder, rulle-, spege-, blod- etc. pølser, ost, sm $\phi$ r, salt og røget kjød, sardiner, portviin, madeira, cigarer, sukker, thee, caffe, salep og alle andre tænkelige og utænkelige spiselige og uspiselige (blфdkogte æg) sager, saa kan du nok tænke dig, at man kan faae et gandske ordentlig maaltid ud deraf; især naar vi tager doctorens bitter med $\mathrm{i}$ beregning, foruden baiersk $\phi \mathrm{l} \mathrm{og}$ fortrinligt hvedebrød fra Augustenborg.

I s $\varnothing$ ndags var det jo lille Idas høie fødselsdag. I den anledning havde vi et lille middagsgilde, retterne bestod af: 1) r $\varnothing$ get oxetunge med stuvede grønærter og asparges, hermetisk tilproppede fra Kjøbenhavn, 2) boeuf (og det noget af det bedste, jeg har smagt) med kartofler, 3) br $\phi d$, sm $\varnothing \mathbf{r}$ og ost, 4) dessert, bestaaende af confect og krakmandler, appelsiner og andre sydfrugter. Vinene: rødvin (Leoville), portviin, madeira og champagne, dernæst caffe og saa whist. Se under feltforhold er det slet ikke saa daarligt præsteret, naar man tager $i$ betragtning, at vi selv ar- 
rangerer det. Hver aften have vi os en gemytlig l'hombre, hvori overlægen, Wroblewsky som oftest deltager, det er ogsaa en gandske gemytlig fyr. Men det er vel bedst, at jeg siger stop med den snak, for ellers l $\phi$ ber jeg vist for langt. Lad mig engang vide, hvorledes det nu staaer til i Kjøbenhavn med revolverne, om de nu er til at faae; den, jeg havde med var noget snavs, man kunde risikere, at den efter det f $\varnothing$ rste skud gjorde sig udtilbeens og ikke vilde meere, det var en gammel, raadden djævel, som jeg er glad til at være bleven qvit; jeg har solgt den for indkj $\varnothing b s p r i s e n$. Men imidlertid er netop i en krig, som den vi nu f $\phi$ re, hvor bajonetangreb og skandsefægtninger hører til dagens orden, ere revolvere noget af det hensigtsmæssigste. Skulde du kunde opdrive en saadan til omkring 25 rdl., var det slet ikke af veien. Ved leilighed skal jeg saa sende pengene. - Jeg vilde egentlig dennegang have skrevet til fader, men saa kom jeg til at tænke paa, at du nu i saa lang tid slet ingen brev har faaet; derfor faaer du nu dette; men vil du hilse fader og takke mange gange for hans brev, mere kjærkomment brev kunde jeg ikke faae. Med det allerførste skriver jeg til fader. Hils saa vor kjære moder, siig, at mit høieste $\varnothing$ nske er, at $i$ alle derhjemme maae bevare et ligesaagodt humeur som jeg, og nære samme tillid til den gode stjerne, der hviler over mig. Hils Ida, hendes skaal blev tømt til bunden (champagne naturligviis), hils ogsaa Engeline mange gange, sp $\phi r g$ hende, hvormeget hun vil have pr. time for at undervise mig i musik, naar jeg kommer hjem, hun maa tage $i$ betragtning, at jeg muligt bliver vanskelig at lære noget, da mine fingre nu passe bedre for en smedie end for et instrument. Hils saa Dithmers og sig, at jeg just i dette фieblik fik brev fra dem; Tak dem rigtig mange gange derfor, og siig, at inden mange timer skriver jeg til dem, og maae du saa til slut hilse Frederik, Meinung, Emma og Agnes, Schumachers, Basse etc. etc. Saa skal du for denne gang være fri for flere commissioner fra din hengivne broder

\section{Viggo.}

Just som brevet sluttes, have vi faaet ordre til at afmarchere i morgen tidlig kl. 6. Vi skulle paa forpost i Dybb $\varnothing$ lstillingen, saa vidt jeg veed, naar blot foden vil gjøre det. 


\section{4.}

Sebbelev, d. 24. febr. 1864. Kjære fader!

Hvis du af dette brev skulde faae det indtryk, at jeg havde mistet mit humeur og krigslyst, saa tager du ikke saa gandske feil i фieblikket, men jeg haaber ikke, det varer mange dage, inden jeg reiser mig igien. Ingen kan heller fortænke mig deri; min bedste ven og kammerat, min compagnicommandeur, Bruun, er falden; ikke som jeg paa slagdagen skrev, saaret og tagen tilfange; men truffet af en kugle i hjertet, og dernæst paa det skjændigste plyndret, saa at de endog have taget ringene af hans. finger og prøvet paa at skjære st $\emptyset$ vlerne af ham. Lieutenant Helms, et prægtigt menneske, som jeg hver time har været sammen med, siden vi toge fra Kjøbenhavn, er saaret, i heldigste tilfælde fangen, maaske skudt eller saaret. (Vi kaldtes de uadskillelige), 12 af compagniets underofficerer og undercorporaler og c. 60 menige, deels faldne, saarede eller for st $\varnothing$ rstedeelen fangne. Jeg er den eneste officer tilbage ved compagniet, der nu har mistet 4 officerer i denne maaned; og naar man saa tænker sig det samliv, vi førte, saa gemytlig og sorgl $\phi s$, og saa nu seer doctor Videbech og mig sidde tavse her, hvor vi for faae dage siden havde det saa godt, og saa tillige betænker, hvad der er skyld i denne ulykke, da kan virkelig enhver dog forstaae, at vi just ikke have grund til at være glade.

I fredags, d. 19de, marcherede vi om morgenen tidlig til Dybbølstillingen, hvor vi den første dag var i skandserne, den næste dag ude i Dybb $\phi l$ by, og s $\not$ ndag morgen droge vi paa feltvagt igien længere ude, saa at vi omtrent vare $1 / 2$ miil fra skandserne.

Bruun skulde med 2det compagnie danne 6 feltvagter og overspænde en bue paa ca. 1/2 miil. Vi fik da 1/2 comp. i forstærkning, men den stilling, vi da indtoge, var saa skandaløs, at vi umulig kunde undgaae, hvad der paafulgte. Vore vedetter stode næsten overalt saaledes, at de paa grund af foranliggende byer, krat, huse etc. ikke kunde opdage noget fiendtligt, f $\phi \mathbf{r}$ det var lige inde paa dem, og desforuden stod hele vedetkjæden, især paa vor venstre fløi, i en saadan bue, at fjenden, hvad han da ogsaa gjorde, aldeles kunde omgaae os. Det er den uhyggeligste nat, jeg nogensinde har oplevet. Vi vidste alle, hvor farlig og uholdbar 


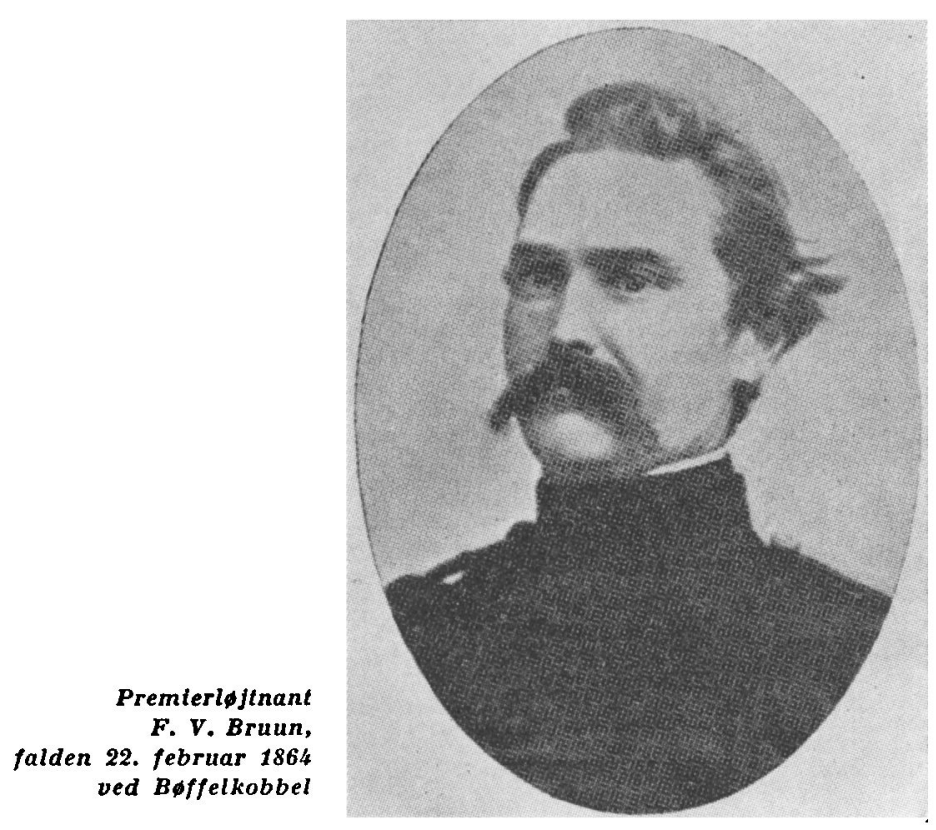

stillingen var, og dygtig trætte vare vi allerede $i$ forveien; da vi de 2 foregaaende dage hvert øieblik havde været allarmerede, og saagodtsom ikke havde sovet. Hver mand stod med geværet i haanden, og en uhyggelig stilhed herskede overalt. Jeg havde min plads $i$ en skov, med en stor landsby 100 alen fra mig. I denne by havde der tidligere været fremskudte poster, men de vare flere dage i rad stadig blevne skudte eller tagne, saa at jeg indskrænkede mig til stadig at sende patrouiller derhen. Den patrouille, der kom tilbage kl. 7 mandag morgen, meldte, at der intet var at observere, men i samme фieblik fik jeg melding fra

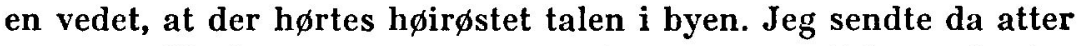
en patrouille derover, og neppe var den kommen til byen, f $\phi \mathbf{r}$ jeg hørte den skyde, og 5 minutter efter myldrede fjenden frem. Jeg skulde holde mig nogen tid der, det harde jeg bestemt ordre til, og jeg gjorde det ogsaa, men da jeg efter flere retirader kom til Dybbøl, havde jeg neppe 10 mand hos mig. Jeg fik da samlet nogle folk fra 18de rgmt af de andre comp., som ogsaa vare splittede, saa at jeg $i$ det hele havde c. 50 mand og gik da ud igien, 
men neppe et qvarteer efter var atter størstedelen af de folk løbne fra mig; og jeg kan virkelig ikke fortænke de folk $i$, at de løb, thi stort valg havde man ikke. Hvordan jeg kom fra det er næsten ubegribeligt, da jeg en tid havde fjenden paa de 3 sider, medens jeg selv med mine folk var paa en aaben mark, hvor der ikke var spor af dækning. Paa vor venstre fløi, hvor netop Bruun opholdt sig, var fjenden, uden at løsne et skud, kommen helt bag om os. De to feltvagter, der stode der, og hvoraf It. Helms var den ene, var rimeligvis tagne til fange. Bruun havde kun 5-6 ordonnanser hos sig, da han opdagede fjenden imellem sig og Dybbølstillingen. Han troede f $\varnothing$ rst naturligvis, at det var vore egne, og raabte til preusserne, at de jo var gale; I skyder jo paa os, raabte han til dem, ere i gale, vi ere jo danske; men snart opdagede han, hvad det var for nogle, og med et par mand, som stødte til ham, omtrent 14 mand, gik han løs paa dem, for at aabne sig en udvei; men idet han stod oppe paa et gjarde og raabte til folkene, at de skulde f $\varnothing$ lge ham, fik han en kugle, saa at han faldt ned paa den anden side, og kort efter kom 2 preussere og bar ham ind i et huus. Deraf sluttede jeg, at han kun var saaret, og det skrev jeg strax til hans familie; men imorges er hans lig bragt ind til S $\phi$ nderborg. Kuglen var gaaet tværs igiennem brystet. Det var en tapper soldat, en prægtig kammerat og en ven, man ikke finder mage til. Jeg skammer mig ikke ved at sige, at jeg har grædt salte taarer ved hans d $\varnothing$ d.

En tung pligt er det ogsaa at skrive til hans familie. Til alt dette kommer, at man paa høiere steder skal have bebreidet 18de rgmt, at det er løben tilbage i en opløst tilstand, og det uagtet jeg kan nævne exempler paa, hvorledes mange har staaet fast og modtaget vel den 10-dobbelte styrke med bajonetterne og mistet halvdelen, uagtet endvidere det jo som følge af den uhyre og tillige meget tynde udstrækning, det som forposter havde, jo næsten $\mathbf{i}$ forveien var opløst, og uagtet endelig, at det var $\mathbf{i}$ det mindste paa den ene fløi aldeles omgaaet, f $\varnothing$ rend der faldt skud. S $\phi$ rgeligt er det at lide saa stort tab (det anslaaes løseligt til henved 400 ), men dobbelt s $\phi$ rgeligt er det at vide, at skylden ligger $i$ en aldeles umulig opstilling, og saa bagefter høre, at de store, der ere skyld deri, omtaler regimentet paa en mindre behagelig 


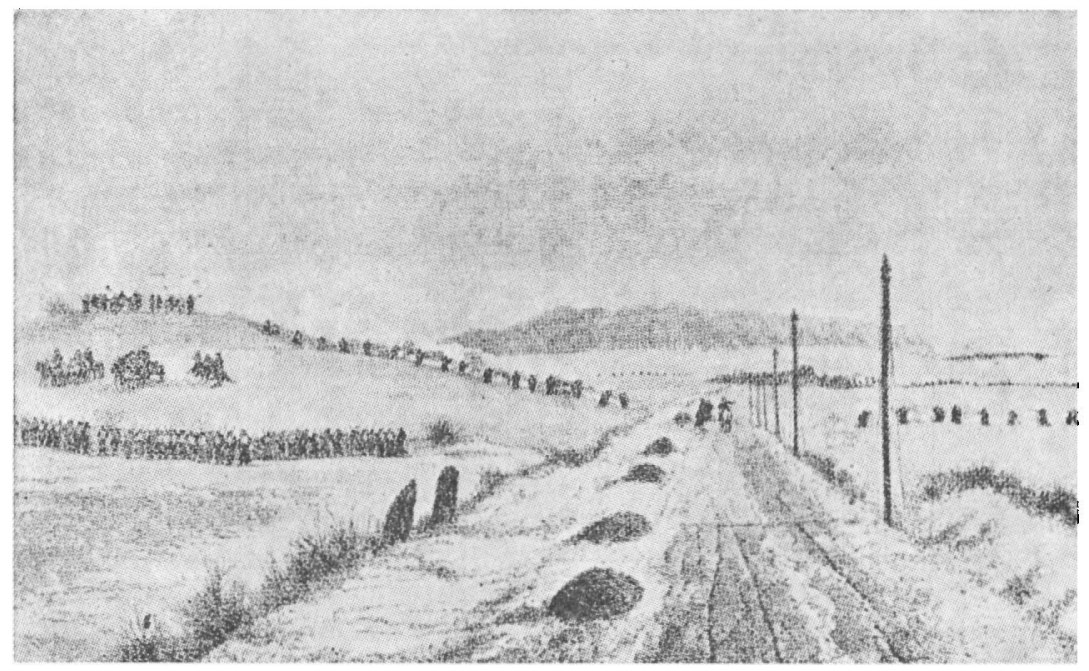

Fagtningen ved Boffelkobbel den 22. februar 186.

maade. Desuden havde vi just dagen f $\phi r$, vi rykkede derud, modtaget 300 forstærkningsmænd, alle slesvigere, og de af dem, som var paa forpost, ere næsten alle forsvundne, naturligviis ere de løbne over; men, naar man læser i aviserne, i Dagbladet f. ex., at de slesvigere, som falde i fiendens hænder, blive frigivne, saa er det jo heller ikke underligt, at de fors $\emptyset$ ge det; dog forekommer det mig ikke aldeles n $\phi$ dvendigt at skrive sligt $i$ en avis. Nu efter den historie er forpoststillingen endelig forandret, men det er virkelig en dyrekjøbt erfaring, og uheldigt er det, at vore folk kun faaer $\emptyset$ velse $i$ at gaae tilbage.

Saa kjære fader, i godt humeur er jeg ikke, og det vilde ogsaa falde mig vanskelig at affectere det; men under forhold, som dem vi leve under, maa man ikke gjerne hænge med hovedet, og vi gjøre alle herovre, hvad vi kunde for at opmuntre hverandre.

Det er en underlig forskjel, der er paa livet paa forpost og $\mathbf{i}$ cantonnement. Derude leve vi meget tarveligt; Du skulde se noget caffe, man fabrikerer, og $i$ cantonnementet leve vi $i$ en overdaadighed, som er forbausende. Doctor Videbeck og jeg boe stadig sammen; tidligere var Bruun og Helms med; vi have et spisekammer saa enormt, at gierne 100 mennesker kunde bespises 
deraf. Pølser, skinker, stege, fjerkræ, viin etc. etc. faar man tilsendt overaltfra. I dette фieblik fik vi viin sendt fra børscommiteen, og nu kom just ogsaa et brev fra Frederik, der bebuder en ny forsyning. Det gjor virkelig godt at vide, at man derhjemme tænker saa meget paa os.

$\mathrm{Nu}$ har jeg faaet kassen fra Dithmers og pakken hjemmefra. Tak de kjære afsendere mange gange. - Imorgen skriver jeg, hvis jeg kan faae tid til Dithmers; hils dem inderlig fra mig. Idas søde lille brev fik jeg om natten paa den uhyggelige feltvagt. Jeg læste det ved skinnet af vagtilden. Hils Engeline mange gange fra mig og $\varnothing n s k$ hende en meget hurtig bedring; det gjorde mig meget ondt at høre, at hun var syg.

Vær nu til slutning forvisset om, kjære fader, at jeg tydelig indseer, det ikke kan hjælpe at tabe modet, og at jeg snart skal komme mig efter det stød, og hils saa alle de kjære derhjemme fra din hengivne søn

Viggo.

P.S. Vort regiment har 6 faldne og saarede officerer, 22 underofficerer og henved 300 menige enten fangne eller saarede og døde.

Husk imidlertid, at alt, hvad jeg beretter af den slags, ikke er for of fentligheden.

Hvis der muligen skulde findes et visitkort portrait af mig, som er tilfalds, da er her et ungt menneske herovre, som jeg meget gjerne vilde give det, og den, jeg derved berøver det, skal snart faae et andet.

$\boldsymbol{v}$.

Skriv strax ud til Ludvig, det er ikke sagt jeg faar tid.

15.

(Brev fra J $\phi$ jtnant Helms til løjtnant Voldbye).

Maugdeburg, d. 1. marts. Min kjære Voldbye!

Endelig er jeg engang igjen kommen til ro og vil da strax skrive til dem og give dem underretning om, hvorledes jeg har det, ligesom jeg har adskilligt at bede dem om; men først og fremmest, hvorledes er alt gaaet til den ulykkelige 22de februar, da jeg blev fangen, jeg havde, som de veed, mine vedetter udstil- 
lede $\mathbf{i}$ den vestlige udkant af B $\phi$ ffelkobbel; om morgenen, just som jeg havde indtaget min dagstilling, hørte jeg pludselig et par skud lige bagved mig, men jeg kunde jo intet see, da jeg havde skov bagved mig, og jeg kunde jo aldrig ane, at fjenden allerede var bag ved os; da jeg imidlertid hørte flere skud i samme retning, blev jeg betænkelig og vilde just sende en patrouille derhen, da der kom en af vore dragoner sprængende, som sagde, at feltvagten skulde tilbage; saa hurtigt som muligt samlede jeg mine folk og gik tilbage, men vi vare allerede afskaarne; jeg vidste jo ikke, hvormange preussere der var i skoven bagved mig, og jeg nærede derfor de sangvinske forhaabninger, at det vilde være mig mueligt at slaae mig igjennem skoven med min feltvagt, vi løber derfor lige paa dem, som var den eneste vei, men de skiøde efter os dog uden at saare mere end et par mand; men da pludselig rykkede mindst 200 mand lige mod os og skiøde paa en afstand af neppe 20 skridt; da de vare saa mange mod os, var ethvert haab om redning umueligt, og det gjalt derfor kun at lade sig tage paa en anstændig maade, og det blev vi, det er dog altid en trøst; thi med undtagelse af et par slesvigere, der kastede deres geværer, saa bleve paa de fleste af de andre af mine folk geværerne med magt revne ud af hænderne, og en kjæmpestor preusser sprang selv lige ind paa livet af mig og vristede mig sabel og revolver ud af hænderne. Saaledes gik dette til; men siig mig nu engang, hvis er skylden for, at vi ere blevne saaledes afskaarne; den maa efter min mening falde paa de feltvagter, der skulde observere Broager Land, thi derfra kom preusserne, og hvis blot de feltvagter havde holdt sig lidt længere og givet os underretning, da skulde vi nok være kommen i ordentlig tid tilbage; men saaledes at blive afskaarne, inden vi vidste et ord deraf, det er dog gandske mærkværdigt. Naturligvis havde de slesvigere, der deserterede om aftenen fra 7. compagni, givet fjenden underretning om, hvor vore forposter stode; idethele er det s $\phi$ rgeligt, at vi have faaet disse slesvigere med; de ere ikke at stole paa, og den næste dag havde de alle skaaret cocarderne af deres kasketter. Strax efter vi vare blevne fangne, blev jeg forestillet for Wrangel og kronprinsen af Preussen, der begge rakte mig deres haand og idethele vare meget forekommende, som overhovedet de preussiske officerer. Hertil Magdeburg kom jeg iforgaars led- 
saget af en preussisk lieutenant; jeg blev strax indlogeret i citadellet, men allerede igaar fik jeg tilladelse til at ops $\varnothing$ ge mig en lejlighed $i$ byen, og jeg har nu lejet et værelse $i$ et hotel-garni, hvor ogsaa lieutenant Hansen af 9de regiment boer; idet hele ere vi 8 officerer, hvoriblandt capitain Weyhe af 1 ste regt., der aldeles ikke har været saaret, som rygtet gik. Vi have lov at gaae frit omkring heri byen, men ikke udenfor. Dagen $f \varnothing r$ jeg kom hertil, havde de fremmede preussiske officerer gjort et gilde, hvortil de danske officerer vare indbudne.

Er lieutenant Bruun falden eller ikke? Jeg hørte af en preussisk officeer paa Graasteen, at han var falden, men i bladene seer jeg intet fast derom. Gjør mig den tjeneste, gode Voldbye, og skriv saa snart som mueligt til mig, og fortæl mig alt; dernæst gjør dem umage for, at jeg snarest mueligt faaer min kuffert sendt hertil, thi jeg har ikke andre klæder end dem, jeg staaer og gaaer $i$, og endelig sp $\phi$ rg intendanten, om han ikke kan sende mig min gage hver maaned, thi de 12 rdl. vi faaer her, kan man hverken leve eller døe af.

Og nu levvel, gode Voldbye, hils alle, og vær forsikret om, at vi alle her intet hellere $\phi$ nske, end at vi igjen vare ved vore afdelinger og kunde dele farer og besværligheder med vore kammerater.

Skriv endelig strax til mig og husk kuffert og intendanten.

Deres

Helms.

Min adresse: Dreibrezel-Strasse no 14. Magdeburg.

16.

Sønderborg, d. 1ste marts 1864. Kjære fader!

Jeg er just kommen ind fra forpost nu $i$ aften og skal ligge her $i$ nat og vil derfor benytte tiden til $i$ en fart at sende et par ord hjem. I s $\emptyset$ ndags afmarcherede vi kl. 5 om morgenen fra Sebelöv og trak ud paa forpost. Vi stode paa feltvagter til mandag formiddag; denne gang lidt bedre end sidst; forpostlinien er nu trukket betydelig tilbage og er meget bedre og sikrere end f $\phi r$. Fra mandag middag til nu $i$ eftermiddag vare vi i skandserne 
og paa skandsearbejde, og imorgen tidlig kl. 7 rykker vi atter paa de yderste forposter. Det er nu saaledes arrangeret, at vi ere 6 dage $i$ cantonnement paa Als og 6 dage ovre i Sundeved. De f $\varnothing$ rste 6 dage ere hviledage; de andre ere vi paa forpost eller i skandserne med een nats hvile i S $\varnothing$ nderborg. (Vor bataillon ligger i kirken).

Denne gang var den forste, siden krigen begyndte, at vi ikke have været $\mathrm{i}$ fægtning, medens. vi vare paa forpost. Det pleier ellers at følges ad, saaledes at naar 18. rgmt. er paa forpost, faar vi altid slagsmaal. Denne gang fik vi kun 1 mand skudt af en patrouille. For $\varnothing v$ rigt befinder jeg mig nu betydelig bedre end sidst; det meget bevægede liv, vi $f \phi r e$, er altid heldigt i saadanne tilfælde. Alene at see det liv og høre soldaternes sludren, især ved deres maaltider, og fremfor alt at see dem lave mad og skaffe eller redde, alt dette er virkelig undertiden meget interessant. Var det blot sommer, da kunde man jo faa det saa prægtigt, som man vilde $\varnothing$ nske det, da vilde jo det forpostliv, som nu i den kulde er yderst anstrengende, næsten være en behagelighed; man kunde da overalt, hvor man nu staaer og roder i snee og dynd, lægge sig ned, og om man end om natten ligger paa marken, kunde man dog sove lidt, hvorimod man nu ikke engang $t \varnothing r$ sætte sig ned, for ikke at fryse fordærvet; men vi maa jo trøste os med, at det værste af vinteren er forbi, og det bliver stadig bedre.

Der er en gammel tro, der siger, at een ulykke eller rettere eet uheld aldrig kommer alene, det er da ogsaa denne gang indtruffet. Vi vare tidligere, som jeg vist har skrevet, 4 i en gemytlig messe. Da Bruun og Helms gik væk, maatte dr. Videbeck og jeg slaae vore pjalter sammen, og glad maa jeg være til, at jeg havde ham i de dage; thi jeg var virkelig $i$ et frygteligt humeur, vi kom overordentlig godt ud af det med hinanden; han var et prægtigt menneske, som jeg holder meget af. Igaar blev han, uden at ane det, forsat til artilleriet, og vi fik en frivillig svensk doctor i stedet; saa nu er jeg alene tilbage. Det kan ikke nægtes, at det var en yderst ubehagelig overraskelse for os begge. Men jeg troer nu næsten, at jeg heldigviis nærmer mig til at være kommen paa det stadium, at jeg tager alt, som det falder, ja, i det første øieblik kan jeg nok blive i daarligt humeur; men det kan ogsaa overvindes, naar man blot vil. Du kan troe, kjære fader, en krig er 
virkelig en god skole for et ungt menneske. Et uvurderligt gode har man, som omtrent erstatter alle de savn, man lider under, og det er tanken om hjemkomsten, den forjager mangt et kjedeligt фieblik! - Jeg har da haft den glæde, at et par stykker af mine folk rimeligviis blive dekorerede efter min indstilling. De 25 rdl. blive denne gang som sædvanlig at hæve $i$ Kjøbenhavn. Jeg sender hermed 20 rdl., som jeg antager ogsaa at kunne spare op i denne maaned. Af dem tilgaae de 7 rdl og 80 sk til musikkassen. Den skal nu indeholde 154 rdl 16 sk. Der er i forveien 128 rdl. For januar er tilgaaet 9 rdl 24 sk, for februar 9 rdl 8 sk og for marts 7 rdl 80 sk. Jeg havde jo ved min afrejse laant 54 rdl af den; de maa lægges til. Ved næste maaneds begyndelse skal jeg vistnok aflægge regnskab for dem. Du er vel nok saa god, kjære fader, at notere de skillinger, jeg sender hjem, og bes $\phi r g e$ husleje og lignende betalt deraf. - Nu er jeg søvnig og maa høre op; kl. er mange, og jeg skal op kl. 5. Du kan tænke dig, jeg kommer i seng inat; ja vi ere rigtignok 2 om en meget lille seng; men det er dog altid noget. - Jeg haaber da, at alle ere raske og vel derhjemme, Engeline er vel ogsaa rask, haaber jeg; og brev faaer jeg vel snart. Hils min søde moder derhjemme og siig, at næste gang faar hun brev, og hils ogsaa de kjære s $\varnothing \mathrm{d}-$ skende, venner og bekjendte fra din hengivne $s \phi n$

Viggo.

17.

Sønderborg, d. 12te marts 1864 .

Kjære broder!

Vil du f $\emptyset$ rst og fremmest hilse fader og sige, at hans brev med bilag fik jeg f $\varnothing$ rst igaar d. 11 te altsaa c. 14 dage, efter at det var skrevet, og det er dog lidt vel længe, det gaaer hurtigere med posten, dernæst skriver fader, at penge $i$ disse tider ere en biting, det indrømmer jeg tildeels, men vil du desuagtet hilse fader og takke ham hjerteligt for det, han veed nok, thi om end ikke guldet glimrer for mig nu med den glands som ellers, saa har en gave som den fra fader dog langt mere værd for mig end meget andet. Vil du tillige takke de andre kjære brevskrivere for deres smaae indlagte epistler, det er morsomt nok at faae breve 
saadan fra hele geleddet. Emilie har vel nu faaet et brev fra mig; ved lejlighed skal jeg ogsaa betænke de andre.

Jeg skrev i Emilies brev, at du skulde faae brev, næste gang jeg skrev, og du seer, jeg holder ord. Dit mærkværdige brev af $29 \mathrm{de}$ f. m. og 9de d. m. fik jeg for lidt siden og griber $i$ en lignende fart pennen for at besvare det, men meget faaer du vist ikke, thi kl. er henad 10 aften, og imorgen tidlig skulde vi paa feltvagt; forrige nat vare vi i skandserne (fuld af utøi der), saa jeg maae sove dygtig i nat, da der næste nat ikke bliver noget deraf. Du skriver en deel om muggenhed etc.; den gaaer ikke, op med næbbet, og vent til jeg kommer hjem; der er saa mange ting, jeg skal snakke med dig om, du kan troe vi skulde slaae en lun passiar af sammen, men du maae faae en ren pibe til mig, og selv stoppe den. - Dernæst kommer jeg til at tænke paa, at lille Ida for længe siden engang skrev til mig, at mit pianoforte ikke var hjemme i St. Kongensgade, og at fader havde sagt, det ikke var mit $\varnothing$ nske, at det blev brugt, jeg har aldeles glemt det siden; men vil du hilse og sige, at jeg meget gerne seer, at det bliver benyttet. - Saa var det om revolveren. En terzerol er maaske ligesaagod; jeg vil rigtignok $\emptyset$ nske og haabe, at jeg aldrig skulde faae brug for en saadan tingest, da den jo egentlig kun kan komme til anvendelse $i$ det tilfælde, at fjenden allerede er kommen $i$ skandserne, men man har dog seet $f \varnothing r$, at den kan komme til anvendelse; og kan man redde sit liv for 12 rdl, saa kan det da egentlig nok betale sig. Send mig derfor kun en terzerol. NB hvis den kan skyde, og desuden ammunition dertil, saa skal du have tak. - Saa var det om Pfeiffer, saa vidt jeg veed, ligger han paa lazarettet; men efter Videbechs udsagn er den gledet af paa ribbenene og er vist ikke saa farlig; idetmindste gik Videbech med ham under armene mindst 1000 alen tilbage under fægtningen. S $\varnothing \mathrm{g}$ ham op, hvis du kan, og hils ham. Det er en flink soldat. Frandsen fik kuglen i albueleddet (indvendig fra), nei det er ikke sandt.

Du kan troe, vi havde igaaer en skiøn forestilling. Hele vor brigade stillede $i$ en forfærdelig veir $i$ dynd op til anklerne og hilste f $\phi$ rst paa vor nye brigadecommandeur, oberst Kauffmann, hver officer blev præsenteret for ham, dernæst inspicerede general Gerlach os og sagde nogle kjønne ord til folkene, og saa kom 
det smukke. - Decorationerne $\mathrm{i}$ anledning af affairen ved Mysunde. Jeg har aldrig seet st $\varnothing$ rre forbavselse, end da der af hele klatten blev (af underclasserne) fremkaldt een, nemlig commandeersergent Madsen, der blev dannebrogsmand (corp. Mфller, som ogsaa blev dannebrogsmand er fangen). Regimentet havde indstillet henad en snees, og om man end ikke ventede, at alle skulde decoreres, saa havde man dog idetmindste ventet flere end 1. Hvad indtryk sligt gjør blandt mandskabet; især naar man tager hensyn til, at affairen ved Mysunde egentlig er den eneste i denne krig, hvor fjenden fik prygl, og dernæst, at mandskabet var trommet sammen til uddeling af decorationer. See, det taler jeg ikke om; men godt var det ikke. See, der tales jo nok om medailler, men det kjender vi fra forrige krig. -

Hvordan gaaer det med den stakkels Engeline, jeg haaber da snart hun er rigtig rask, naar hun bliver det, saa bed hende skrive 2 ord under et brev hjemmefra til mig. Vil du saa hilse vor kjære fader og moder tilligemed Frederik, Ida etc. etc. rigtig mange gange. Paa tirsdag skriver jeg atter, saa ligger jeg om natten i S $\phi$ nderborg.

Imorgen som sagt skal jeg paa forpost; det er en kjedelig tour i dette veir især. Fjenden arbejder nu stærkt paa skandser; men det gaaer vist kun smaat for ham med at kjøre skyts op i det morads.

Der blev dog plads til at tegne mig som din hengivne broder Viggo.

Dagen efter, at Voldbye havde skrevet ovenstaaende brev, besatte regimentet forposterne på venstre fløj, og tidlig næste morgen angreb preusserne Dybb $\not l$ kirke med to kompagnier i første og fire $i$ anden linie, medens to kompagnier gik mod Rageb $\varnothing 1$. Kirkegården var besat af to delinger af 1 . kompagni, medens 2. kompagni stod længere tilbage som piket. Der udviklede sig nu en hård fægtning om det forstærkede kirkegårdsdige, og Voldbye blev sendt frem til præstegårdshaven med sin deling. Det lykkedes de tre delinger at standse det tyske angreb i $1 \frac{1}{2}$ time, og da fjenden så, at der var flere tropper længere tilbage, opgav de deres forehavende og trak sig tilbage. Om eftermiddagen blev 18. regiment afløst og overtog bevogtningen af skandserne. 
Preusserne havde i den foregående tid indrettet batterierne på Broager Land, og den 15. marts kl. 11 åbnede de ilden med 26 piecer navnlig mod skandse 2. Ved den uventede beskydning søgte besætningerne straks ly $i$ blokhusene, men de var kun af svært tømmer med et jorddække beregnet på beskydning fra Sundeved.

En af de første granater gik gennem væggen $i$ blokhuset $i$ skanse 2 og sprang derinde. L $\varnothing$ jtnant Voldbye blev ramt af et sprængstykke $i$ den ene skulder og et andet $i$ brystet og d $\phi$ de straks. Desuden såredes to af hans deling og to artillerister.

Hans d $\varnothing d$ f $\varnothing$ ltes i regimentet som en stor sorg, fordi han var ualmindelig afholdt af foresatte, kammerater og undergivne. Han

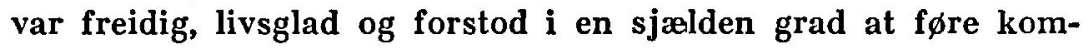
mando med en passende blanding af alvor og lune. Hans lig f $\phi r-$ tes til København og begravedes med militær honn $\varnothing \mathbf{r}$ på Garnisons Kirkegård. Det $f \not l$ lgende brev til hans fader giver et tydeligt begreb om de følelser, der næredes for ham.

\section{8.}

Augustenborg, den 24de marts 1864.

Kjære hr. doctor!

Det er ikke med nogen behagelig f $\varnothing$ lelse, at jeg skriver nærværende linier, og jeg beder dem at være overbeviist om, at jeg i meget høi grad beklager og deler den smerte, som de med høitærede familie maa f $\varnothing l$ le over tabet af en s $\phi$ n, til hvem de med rette havde saa store forhaabninger, som det her var tilfældet. - Idet jeg altsaa herved beder dem, med ærede frue, samt børn og $\varnothing v$ vige familie, at modtage min hjerteligste condulation i anledning af dette h $\phi$ ist s $\phi$ rgelige og beklagelige dødsfald, kan jeg dog ikke nægte, at det i deres store sorg maa være dem til betydelig trøst at kjende det i høi grad, hæderlige og fordeelagtige vidnesbyrd, som hans foresatte, kammerater og undergivne ere enige om at give, som sdygtig og brav officeer, tapper soldat, god kammerat og behagelig, human foresatte«, thi de kan være vis paa, at kun faae have et saa hæderligt eftermæle, og at hans er fortient, derom vidne alle udtalelser af dem, som kjendte den salig afdøde eller havde staaet $\mathrm{i}$ noget forhold til ham. - 
De bedes undskylde, at jeg forinden min bortreise ikke fik tid til at aflægge dem en skyldig visit for at tage afsked med dem, men det høist uventede ved dette tilfælde $i$ forening med den korte frist, som blev mig til deel ved denne leilighed, maa tiene mig som undskyldning af en pligtfølelse, som jeg under andre omstændigheder ikke vilde have gjort mig skyldig $\mathbf{i}$. -

Slutteligen bedes de, med ærede frue, b $\phi \mathbf{r n}$ og hele familie at modtage min hjerteligste hilsen, de selv hilses f $\varnothing \mathrm{rst}$ og sidst fra deres forbindtlige

\section{Müller.}

\section{NOTER}

1) Kaptajn Ludvig Carl Christian Maximilian Schow, 1827-1864. Mistede 1849 sin højre arm ved Kolding. Falden ved Mysunde.

2) Løjtnant Henrik Steffens Helms, 1835-1914. Kaptajn, skolebestyrer.

9) Lægerne: konstitueret overlæge Johannes Julius Wroblewsky, 1820 -1888. Kommunelæge i København, konstitueret underlæge Carl Alexis Henrik Bernhard Videbeck, 1836-1889 stiftsphysikus.

4) Løjtnant Jørgen Hansen, 1839-1905, oberstløjtnant.

s) Stillingen ved Mysunde lå tat syd for byen og bestod af to skanser og en skyttegrav tvars over den ca. $400 \mathrm{~m}$ brede tange.

-) Premierløjtnant Frederik Wilhelm Bruun, 1832-1864. 16 år gammel frivillig i 1848, 1849 sekondløjtnant. Falden ved Bøffelkobbel.

7) Forpoststillingen gik fra Vemming Bund ved Stenbæk over Sm $\varnothing \mathbf{l}$ vejen, sønden og vesten om Bøffelkobbel og Stenderup skove. I tæt snefog fra vest $1 \phi b$ fire preussiske bataljoner feltvagten ved Sm $\varnothing l-$ vejen og pikettet ved Hvilehøj over ende og afskar derved feltvagterne i skovene, der samtidig blev angrebet af tre bataljoner fra Nybøl. Premierløjtnant Bruun opholdt sig ved Jørgen Finks hus og faldt der.

8) svensk cand. med. \& chir A. Eckerbom.

๑) Terzerol, lille lommepistol.

RETTELSE til 1. halvbind 1961 side 104 tredie sidste linie: andens skyld, læs: ordens skyld. 